\title{
Assessment of zinc bioavailability: studies in rats on zinc absorption from wheat using radio- and stable isotopes
}

\author{
BY THOMAS E. FOX, SUSAN J. FAIRWEATHER-TAIT, JOHN EAGLES \\ AND S. GABRIELLE WHARF \\ AFRC Institute of Food Research, Norwich Laboratory, Norwich Research Park, Colney, \\ Norwich NR4 $7 U A$
}

(Received 11 January 1993 - Accepted 4 March 1993)

\begin{abstract}
Absorption from wheat intrinsically and extrinsically labelled with ${ }^{67} \mathrm{Zn}$ and extrinsically labelled with ${ }^{65} \mathrm{Zn}$ was measured from ${ }^{67} \mathrm{Zn}$ faecal excretion and ${ }^{65} \mathrm{Zn}$ whole-body retention in rats. There were significant differences between the extrinsically- and intrinsically-labelled ${ }^{67} \mathrm{Zn}(P<0.001)$, but not between the extrinsically-labelled ${ }^{65} \mathrm{Zn}$ and intrinsically-labelled ${ }^{67} \mathrm{Zn}$. The effect of chicken meat on the absorption of $\mathrm{Zn}$ from intrinsically-labelled wheat was also studied in the rat. Mean $\mathrm{Zn}$ absorption from wheat and chicken meat fed separately was 18.5 and $68.2 \%$ respectively, and from a mixture of the two containing the same level of $\mathrm{Zn}$ was $50 \cdot 1 \%$. The apparent absorption of $\mathrm{Zn}$ from the composite meal was significantly higher than predicted from the results of the foods on their own $(P<0.001)$.
\end{abstract}

Zinc: Absorption: Stable isotopes

The use of radioisotopes as extrinsic labels for $\mathrm{Zn}$ bioavailability studies is generally accepted as a valid technique (Evans \& Johnson, 1977; Meyer et al. 1983; Flanagan et al. 1985; Gallagher et al. 1988), although some reports have questioned the method (Ketelson et al. 1984). In recent years there has been interest in the use of stable isotopes as a safe alternative to study $\mathrm{Zn}$ metabolism, particularly in infants and pregnant women. However, there are difficulties associated with the use of stable isotopes, notably the assumption that they can be used like radioisotopes to label foods extrinsically (Janghorbani et al. 1982; Serfass et al. 1989; Egan et al. 1991; Fairweather-Tait et al. 1991). First, there is the question as to whether or not extrinsic labels mimic native food $\mathrm{Zn}$ in the gastrointestinal tract during the process of digestion and absorption. Recent studies suggest that the type and physical state of the food has a more important bearing on the behaviour of the isotope and that it is this food-label interaction which determines its absorption process (Fairweather-Tait et al. 1991). Second, there is a large difference in the amounts of $\mathrm{Zn}$ added in the process of extrinsic labelling when using radio- and stable isotopes. The present study was designed to compare the absorption of stable and radio- $\mathrm{Zn}$ used as extrinsic labels in wheat, with intrinsically-incorporated stable $\mathrm{Zn}$.

Many dietary factors affect $\mathrm{Zn}$ bioavailability (Solomons, 1982) and there is some evidence to suggest that meat enhances $\mathrm{Zn}$ absorption from non-meat sources (Shah \& Belonje, 1981). This has been attributed to the level of protein in the diet and, more specifically, to the level and type of amino acids present. A number of workers have tried to demonstrate changes in $\mathrm{Zn}$ absorption with various protein diets with conflicting results (Snedeker \& Greger, 1981, 1983; Colin et al. 1983; Greger \& Mulvaney, 1985). Using whole-wheat and chicken meat, both intrinsically labelled with ${ }^{67} \mathrm{Zn}$, we conducted an experiment to see what influence chicken meat had on the absorption of wheat $\mathrm{Zn}$ in a mixed meal fed to rats. 


\section{MATERIALS AND METHODS}

\section{Animals and diets}

Male Wistar weanling rats, weighing $50 \mathrm{~g}$ each, were randomly allocated into groups of fourteen (Expts 1 and 3) or nineteen (Expt 2), and housed individually in stainless-steel wire-bottomed plastic cages. They were fed ad lib. on a semi-synthetic diet (Table 1), for 1 week, followed by 2 weeks of meal-feeding (two $1 \mathrm{~h}$ meal feeds daily) before the test meal. In all the experiments the rats were fasted overnight before administration of the test meal the following morning, and weighed $210-228 \mathrm{~g}$. During the period of faecal collection the rats were fed on a low-Zn semi-synthetic diet which was similar to that described in Table 1 , but without the added $\mathrm{Zn}$. This minimized re-excretion of absorbed $\mathrm{Zn}$ isotope from the test meal (Fairweather-Tait et al. 1985). Any test meal not completely eaten by the rats was dried and weighed and deducted from the original weight given to the rat to calculate the administered dose.

Two experiments were performed to investigate the effect of labelling techniques of $\mathrm{Zn}$ on $\mathrm{Zn}$ absorption in a wheat meal fed to rats: Expt 1, two groups of fourteen rats were fed on a meal of $7 \mathrm{~g}$ wheat with ${ }^{67} \mathrm{Zn}$ either as an extrinsic or as an intrinsic label; Expt 2, one group of nineteen rats was fed on a meal of $7 \mathrm{~g}$ wheat intrinsically labelled with ${ }^{67} \mathrm{Zn}$, to which ${ }^{65} \mathrm{Zn}$ was added as an extrinsic label.

A third experiment was performed in which the effect of a dietary modifier of $\mathrm{Zn}$ absorption (meat) on wheat was investigated: Expt 3, the effect of chicken meat on $\mathrm{Zn}$ absorption from wheat was studied using chicken meat and wheat intrinsically labelled with ${ }^{67} \mathrm{Zn}$ prepared as described elsewhere (Fox et al. 1991). Three groups of fourteen rats each were used : group 1 , fed on $6.0 \mathrm{~g}$ wheat; group $2,7 \cdot 2 \mathrm{~g}$ chicken meat; group $3,3.6 \mathrm{~g}$ chicken meat mixed with $3.0 \mathrm{~g}$ wheat. These quantities were calculated to obtain the same total amount of $\mathrm{Zn}$ in each meal.

\section{Preparation of test meals}

The test meals were prepared by adding an equal weight of distilled water to the dried food to which a faecal marker of $\mathrm{Cr}_{2} \mathrm{O}_{3}(5 \mathrm{mg} / \mathrm{g})$ had been added, and mixing thoroughly to a paste a few hours before being offered to the rat. Extrinsically-labelled ${ }^{67} \mathrm{Zn}$ wheat was prepared by adding a solution of elemental $\mathrm{Zn}\left(91.9 \%{ }^{67} \mathrm{Zn}\right.$ (atom \%); Technical and Optical Equipment, London)) dissolved in a minimum volume of $\mathrm{HCl}(\mathrm{AR})$ and made up to a suitable volume with distilled water to non-enriched wheat $2 \mathrm{~h}$ before consumption. The test meal labelled with the radioisotope ${ }^{65} \mathrm{Zn}$ was prepared by adding $18.5 \mathrm{kBq}{ }^{65} \mathrm{Zn}$ $\left(\mathrm{ZnCl}_{2}\right.$; Amersham International) to $7 \mathrm{~g}^{67} \mathrm{Zn}$-enriched wheat, prepared as described previously (Fox et al. 1991). The non-enriched wheat was grown from the same batch of seeds and under the same conditions as the enriched wheat. Both the enriched and nonenriched forms of wheat were milled through a $250 \mu \mathrm{m}$ gauge sieve after air-drying.

\section{Measurement of apparent ${ }^{67} \mathrm{Zn}$ absorption}

Individual faecal collections were made for each rat, starting on the day of the test meal and finishing $36 \mathrm{~h}$ after all the $\mathrm{Cr}_{2} \mathrm{O}_{3}$ had been excreted, a period usually lasting 5-6 d. The faeces were dried at $80^{\circ}$, ground and heated to $480^{\circ}$ for $48 \mathrm{~h}$ in silica crucibles. Portions of the ash $(0.025 \mathrm{~g})$ were weighed, taken up in $\mathrm{HCl}$ and analysed by atomic absorption spectrophotometry for total Zn (Fairweather-Tait \& Southon, 1989). Similarly, 0.2 g of the ash was taken up in $\mathrm{HCl}$, concentrated and purified on an ion-exchange column (Fairweather-Tait et al. 1989) and eluted for isotope analysis by thermal-ionization mass spectrometry using a Finnigan MAT Thermoquad mass spectrometer (Eagles et al. 1989). 
Table 1. Composition of the semi-synthetic diet given to the rats $(\mathrm{g} / \mathrm{kg})$

\begin{tabular}{ll}
\hline \hline & 309 \\
Maize starch & 309 \\
Sucrose & 200 \\
Casein & 40 \\
Cellulose & 80 \\
Maize oil & 40 \\
Mineral mix* & 20 \\
Vitamin mix* & $2 \cdot 5$ \\
\hline
\end{tabular}

* Micronutrients were formulated to provide normal requirements for growth (Fairweather-Tait et al. 1991).

Table 2. Analysis of test meals

\begin{tabular}{lcccc}
\hline \hline Food & Isotope label & ${ }^{67} \mathrm{Zn}(\mu \mathrm{g} / \mathrm{g})$ & $\mathrm{Zn}(\mu \mathrm{g} / \mathrm{g})$ & Total Zn in meal (mg) \\
\hline Wheat (Expts 1 and 2) & Intrinsic & $14 \cdot 86$ & $62 \cdot 75$ & $0 \cdot 44$ \\
Wheat (Expt 1) & Extrinsic & $4 \cdot 23$ & $60 \cdot 63$ & $0 \cdot 42$ \\
Wheat (Expt 3) & Intrinsic & $10 \cdot 14$ & $66 \cdot 00$ & $0 \cdot 40$ \\
Chicken (Expt 3) & Intrinsic & $5 \cdot 71$ & $48 \cdot 06$ & $0 \cdot 35$ \\
Wheat and chicken (Expt 3) & Intrinsic & $8 \cdot 17$ & $59 \cdot 32$ & $0 \cdot 37$ \\
\hline
\end{tabular}

Total ${ }^{67} \mathrm{Zn}$, over and above natural abundance, was calculated for the test meal (Table 2) and the faecal samples (Fairweather-Tait et al. 1991), and apparent absorption calculated by deducting faecal ${ }^{67} \mathrm{Zn}$ from the administered dose.

\section{Measurement of ${ }^{65} \mathrm{Zn}$ absorption}

In Expt 2 the animals were counted in a small-animal whole-body counter (NE 8112; Nuclear Enterprises, Beenham, Berks.) immediately after they had consumed the test meal on day 1 and again on each day between day 7 and day 14 (Fairweather-Tait \& Wright, 1984). Each time the animals were counted the results obtained were corrected for background radiation, decay and counting efficiency and the resulting values expressed as a percentage of those obtained on day 1 .

\section{Statistical analysis}

Results from Expts 1 and 2 were compared by $t$ tests, and Expt 3 by $\chi^{2}$ test.

\section{RESULTS}

The results for all three experiments are illustrated in Fig. 1. In Expt 1 mean apparent $\mathrm{Zn}$ absorption results for the wheat extrinsically and intrinsically labelled with ${ }^{67} \mathrm{Zn}$ were $30 \cdot 3$ (SD 3.7$)$ and 22.3 (SD 4.1$) \%$ for the two groups of rats respectively, demonstrating a highly significant difference in absorption $(P<0.001)$ between the differently labelled forms of wheat.

In Expt 2 statistical analysis of the data using the day 7 apparent absorption results in animals given the wheat meal labelled with two isotopes $\left({ }^{67} \mathrm{Zn}\right.$ intrinsic, ${ }^{65} \mathrm{Zn}$ extrinsic) showed no difference. Mean $\mathrm{Zn}$ absorption by the rats consuming a test meal containing $0.44 \mathrm{mg} \mathrm{Zn}$ (of which $103 \mu \mathrm{g}$ was ${ }^{67} \mathrm{Zn}$ ) was calculated to be 20.7 (SD 4.4 ) $\%$ from the ${ }^{65} \mathrm{Zn}$ data and 19.8 (SD 6.2) \% from the ${ }^{67} \mathrm{Zn}$ data. 


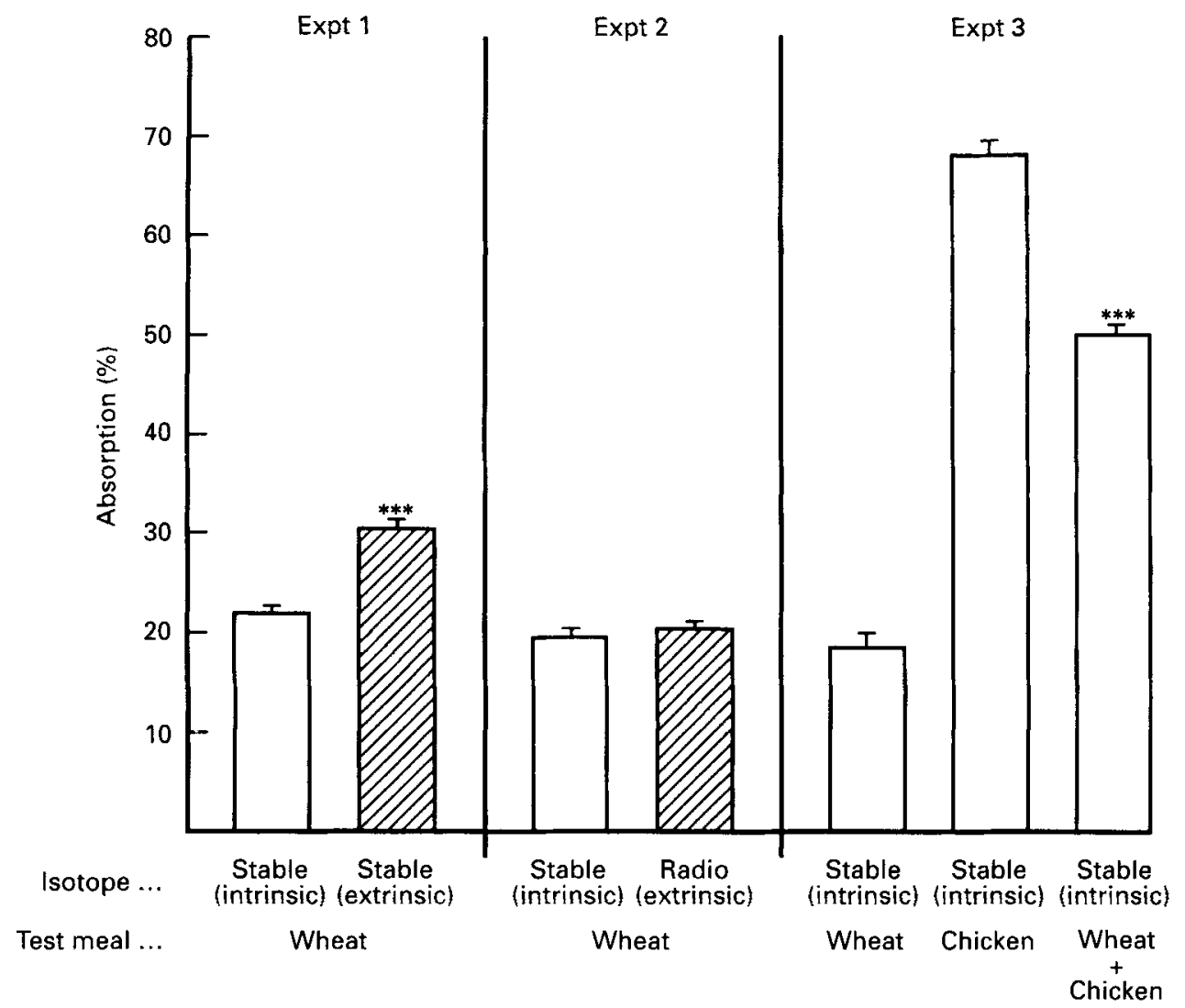

Fig. 1. $\mathrm{Zn}$ absorption (\% of dose) from ${ }^{67} \mathrm{Zn}$ intrinsically- $(\square)$ and extrinsically- ( intrinsically- $(\square)$ and ${ }^{65} \mathrm{Zn}$ extrinsically- (国) labelled wheat (Expt 2), and ${ }^{67} \mathrm{Zn}$ intrinsically-labelled ( $\square$ ) wheat, chicken and wheat and chicken mixture (Expt 3). For details of test meals and procedures, see Tables 1 and 2 and pp. 96-97. Values are means and standard deviations represented by vertical bars. In Expt 1 mean values were significantly different: ${ }^{* * *} P<0.001$. In Expt 3 the mean for the chicken and wheat meal was significantly higher than that predicted from values for the individual chicken and wheat meals: ${ }^{* * *} P<0.001$.

In Expt 3 the mean apparent absorption of $\mathrm{Zn}$ for the three groups of rats consuming test meals of intrinsically-labelled wheat, chicken meat and a mixture of both were 18.5 (SD 6.6), 68.2 (SD 5.6) and 50.1 (SD 4.3) \% respectively. The $\mathrm{Zn}$ content of the three test meals were similar.

\section{DISCUSSION}

The explanation for the difference in apparent absorption in Expt 1 between the wheat meals containing extrinsic or intrinsic ${ }^{67} \mathrm{Zn}$ probably lies in the addition of the isotopic $\mathrm{Zn}$ as an extrinsic label. In Expt 2, where the contribution made by ${ }^{65} \mathrm{Zn}$ extrinsic label to the overall $\mathrm{Zn}$ content was negligible, no difference was found between the intrinsically- and extrinsically-labelled wheat. The native $\mathrm{Zn}$, labelled or otherwise, was chemically and physically associated within the matrix of the food, whereas the extrinsic stable isotope was added in an aqueous phase. Absorption may have taken place, therefore, at a different time and site within the small intestine. It is possible that the extrinsic ${ }^{67} \mathrm{Zn}$ label was more available for absorption, provided that it was not involved in chemical interactions and associations leading to the formation of complexes that would render it unavailable for absorption. The radioisotope, on the other hand, was virtually carrier-free and, with an 
extremely low quantity of $\mathrm{Zn}$, was more likely to behave in the same manner as the intrinsic $\mathrm{Zn}$. It would appear that isotopic exchange that occurred during mixing of the test meal allowed complete exchange of the small amount of ${ }^{65} \mathrm{Zn}$ present, resulting in the formation of a common pool of exchangeable $\mathrm{Zn}$, in which the behaviour of the radioisotope represented that of the native $\mathrm{Zn}$.

Using stable isotopes to label foods extrinsically for bioavailability studies has the disadvantage of the need to add relatively large quantities of $\mathrm{Zn}$ to a food or meal which already has its full complement of $\mathrm{Zn}$ within the food. It has been shown that $\mathrm{Zn}$ absorption from the gastrointestinal tract is not a linear function of $\mathrm{Zn}$ content and that the fractional absorption of $\mathrm{Zn}$ decreases markedly at concentrations above $70 \mu \mathrm{mol}$ in humans (Sandstrom \& Cederblad, 1980; Wada et al. 1985). It is impossible to avoid adding significant quantities of isotopically-enriched $\mathrm{Zn}$ in order to enrich the faeces sufficiently after dilution with dietary and endogenous $\mathrm{Zn}$. Multi-labelling techniques, using smaller quantities of isotope over longer periods of time, can be employed to avoid the problem of giving excessive amounts of $\mathrm{Zn}$ in individual meals. However, it is still not certain that the isotope will behave in exactly the same way as the native $\mathrm{Zn}$ bound in the food matrix, and re-excretion of the absorbed label over a longer time-period would have to be taken into account, making interpretation of results difficult.

By using the ${ }^{65} \mathrm{Zn}$ whole-body retention data from day 7 to day 14 in Expt 2 it is possible to estimate endogenous excretion of $\mathrm{Zn}$ during the first $7 \mathrm{~d}$ and, hence, calculate true absorption (Fairweather-Tait \& Southon, 1989). No significant difference was found between true absorption $(21.5 \%)$ and retention on day $7(20.7 \%)$ when compared with retention calculated from faecal monitoring following administration of intrinsicallylabelled ${ }^{67} \mathrm{Zn}(19 \cdot 8 \%)$. This was not surprising since the study was designed to minimize endogenous $\mathrm{Zn}$ excretion by feeding a low- $\mathrm{Zn}$ diet during the period of faecal collection. However, since endogenous excretion increases with dietary $\mathrm{Zn}$ (Turnlund et al. 1986) higher intakes of $\mathrm{Zn}$ could lead to an underestimation of absorption and, hence, incorrect assessment of $\mathrm{Zn}$ bioavailability.

The results from the wheat and chicken mixed meal demonstrated a significantly higher $\mathrm{Zn}$ absorption from the composite test meal $(50 \cdot 1 \%)$ than that predicted $(43.4 \%)$ from the results of the individual wheat and chicken test meals $(P<0.001)$. This increase in absorption could be due to either of the two sources of $\mathrm{Zn}$ being more efficiently absorbed. However, it would seem more likely that the observed increase in $\mathrm{Zn}$ absorption was due to an increase in absorption of $\mathrm{Zn}$ from the wheat fraction since $\mathrm{Zn}$ absorption from chicken meat was already $68 \%$, a value similar to previous findings for the absorption of chicken meat in rats (Fairweather-Tait et al. 1990). There is some evidence to suggest that the inhibitory effect of phytate on $\mathrm{Zn}$ absorption from wheat is reduced in the presence of protein. Shah \& Belonje (1981), using a rat femur assay technique, found that mixing beef with textured soya-bean protein increased the relative biological value of $\mathrm{Zn}$ from the soyabean product from 47 to $94 \%$, and beef mixed with rapeseed protein concentrate increased from 53 to $83 \%$. Other work by Sandstrom et al. (1989) in human subjects demonstrated a $50-70 \%$ increase in $\mathrm{Zn}$ absorption from a bean meal as a result of doubling the protein in the meal. Both wheat and beans contain phytate which is known to inhibit $\mathrm{Zn}$ absorption and it has been suggested that protein or peptides form complexes with $\mathrm{Zn}$, thereby preventing the formation of Zn phytate (Sandstrom et al. 1980). Other possibilities are that natural mineral chelates exist in animal protein (Scott \& Zeigler, 1963), or that peptides and amino acids, formed during digestion, increase $\mathrm{Zn}$ solubility and facilitate its absorption.

These studies demonstrate that there is a need for caution when employing a stable isotope of $\mathrm{Zn}$ as an extrinsic label for $\mathrm{Zn}$ bioavailability studies. However, the use of radio$\mathrm{Zn}\left({ }^{65} \mathrm{Zn}\right)$ to label wheat extrinsically appears to be a valid technique. The advantage of 
using stable isotopes to label foods is that multi-isotope studies can be carried out. Interactions between three foods within the same meal, each labelled with a different isotope of $\mathrm{Zn}\left({ }^{67} \mathrm{Zn},{ }^{68} \mathrm{Zn},{ }^{70} \mathrm{Zn}\right.$ ) can be investigated, and by using ${ }^{65} \mathrm{Zn}$ a further food can be labelled. The results presented in the present paper have also demonstrated that the absorption of $\mathrm{Zn}$ from a meal cannot be taken to be the sum of the individual foods. In conclusion, the assessment of $\mathrm{Zn}$ bioavailability in a food or meal is influenced by the presence of other dietary constituents and its measurement is affected by the isotopiclabelling techniques employed.

The authors would like to thank Valerie Russell and Angela Twaite for their assistance with the animals. The work was supported in part by the Ministry of Agriculture, Fisheries and Food.

\section{REFERENCES}

Colin, M. A., Taper, L. J. \& Ritchley, S. J. (1983). Effect of dietary zinc and protein levels in the utilization of zinc and copper by adult females. Journal of Nutrition 113, 1480-1488.

Eagles, J., Fairweather-Tait, S. J., Portwood, D. E., Self, R., Golz, A. \& Heumann, K. G. (1989). Comparison of fast atom bombardment mass spectrometry and thermal ionization quadrupole mass spectrometry for the measurement of zinc absorption in human nutrition studies. Analytical Chemistry 61, 1023-1025.

Egan, C. B., Smith, F. G., Houk, R. S. \& Serfass, R. (1991). Zinc absorption in women : comparison of intrinsic and extrinsic stable isotope labels. American Journal of Clinical Nutrition 53, 547-553.

Evans, G. W. \& Johnson, P. E. (1977). Determination of zinc availability in foods by the extrinsic label technique. American Journal of Clinical Nutrition 30, 873-878.

Fairweather-Tait, S. J., Fox, T. E., Wharf, S. G., Eagles, J., Crews, H. M. \& Massey M. (1991). Apparent zinc absorption by rats from foods labelled intrinsically and extrinsically with ${ }^{67} \mathrm{Zn}$. British Journal of Nutrition 66 , $65-71$.

Fairweather-Tait, S. J., Portwood, D. E., Symss, L., Eagles, J. \& Minski, M. J. (1989). Iron and zinc absorption in human subjects from a mixed meal of extruded and non extruded wheat bran and four. American Joumal of Clinical Nutrition 49, 151-155.

Fairweather-Tait, S. J. \& Southon, S. (1989). Studies of iron:zinc interactions in adult rats and the effect of iron fortification of two commercial infant weaning products on iron and zinc status of weanling rats. Journal of Nutrition 119, 599-606.

Fairweather-Tait, S. J. \& Wright, A. J. A. (1984). The influence of previous iron intake on the estimation of bioavailability of Fe from a test meal given to rats. British Journal of Nutrition 51, 199-208.

Fairweather-Tait, S. J., Wright, A. J. A., Cooke, J. \& Franklin J. (1985). Studies of zinc metabolism in pregnant and lactating rats. British Journal of Nutrition 54, 401-413.

Flanagan, P. R., Cluett, J., Chamberlain, M. J. \& Valberg, L. S. (1985). Dual-isotope method for determination of human zinc absorption: the use of a test meal of turkey meat. Journal of Nutrition 115, 111-122.

Fox, T. E., Fairweather-Tait, S. J., Eagles, J. \& Wharf, S. G. (1991). Intrinsic labelling of different foods with stable isotope of zinc $\left({ }^{67} \mathrm{Zn}\right)$ for use in bioavailability studies. British Journal of Nutrition 66, 57-63.

Gallagher, D. D., Johnson, P. E., Hunt, S. R., Lykken, G. I. \& Marchello, M. J. (1988). Bioavailability in humans of zinc from beef: intrinsic versus extrinsic labels. American Journal of Clinical Nutrition 48, 350-354.

Greger, J. L. \& Mulvaney, J. (1985). Absorption and tissue distribution of zinc, iron and copper by rats fed diets containing lactalalbumin, soy and supplemental sulphur containing amino acids. Journal of Nutrition 115 , 200-210.

Janghorbani, M., Istfan, N. W., O'Pagounes, J., Steinke, F. H. \& Young, V. R. (1982). Absorption of dietary zinc in man: Comparison of intrinsic and extrinsic labels using triple stable isotope method. American Journal of Clinical Nutrition 36, 537-545.

Ketelson, S. M., Stuart, M. A., Weaver, C. M., Forbes, R. M. \& Erdman, J. W. (1984), Bioavailability of zinc to rats from defatted soy flour, acid precipitated soy concentrate and neutralised soy concentrate as determined by intrinsic and extrinsic labelling techniques. Journal of Nutrition 114, 536-542.

Meyer, N. R., Stuart, M. A. \& Weaver, C. M. (1983). Bioavailability of zinc from defatted flour, soy hulls and whole eggs as determined by intrinsic and extrinsic labelling techniques. Journal of Nutrition 113, 1255-1264.

Sandstrom, B., Almgren, A., Kivisto, B. \& Cederblad, A. (1989). Effect of protein level and protein source on zinc absorption in humans. Journal of Nutrition 119, 48-53.

Sandstrom, B., Arvidsson, B., Cederblad, A.\& Bjorn-Rasmussen, E. (1980). The significance of wheat extraction rate, zinc, calcium, and protein content in meals based on bread. American Journal of Clinical Nutrition 33, 739-745.

Sandstrom, B. \& Cederblad, A. (1980). Zinc absorption from composite meals 11. Influence of the main protein source. American Journal of Clinical Nutrition 33, 1778-1783. 
Scott, M. L. \& Ziegler, T. R. (1963). Evidence for natural chelates which aid in the utilization of zinc by chicks. Journal of Agricultural and Food Chemistry 11, 123-125.

Serfass, R. E., Ziegler, E. E., Edwards, B. B. \& Houk, R. S. (1989). Intrinsic and extrinsic stable isotopic Zn absorption by infants from formulas. Journal of Nutrition 119, 1661-1669.

Shah, B. G. \& Belonje, B. (1981). Bioavailability of zinc in beef with and without plant protein. Federation Proceedings, no. 3552, vol. 40. Ottawa: Food Directorate, Health and Welfare.

Snedeker, S. M. \& Greger, J. L. (1981). Effects of dietary protein, sulphur amino acids and phosphorus on human trace element metabolism. Nutrition Reports International 23, 853-864.

Snedeker, S. M. \& Greger, J. L. (1983). Metabolism of zinc, copper and iron as affected by dietary protein, cysteine and histidine. Journal of Nutrition 113, 644-652.

Solomons, N. W. (1982). Biological availability of zinc in humans. American Journal of Clinical Nutrition 35, $1048-1075$.

Turnland, J. R., Durkin, N., Costa, F. \& Margen, S. (1986). Stable isotope studies of zinc absorption and retention in young and elderly men. Journal of Nutrition 116, 1239-1247.

Wada, L., Turnland, J. R. \& King, J. C. (1985). Zinc utilization in young men fed adequate and low zinc intakes. Journal of Nutrition 115, 1345-1354. 